\title{
Life history variation and demography of the invasive plant Eschscholzia californica Cham. (Papaveraceae), in two altitudinal extremes, Central Chile
}

\section{Variación de historias de vida y demografía de la planta invasora Eschscholzia californica Cham. (Papaveraceae) en dos extremos altitudinales, Chile central}

\author{
Francisco T. Peña-Gómez \& Ramiro O. Bustamante* \\ Departamento de Ciencias Ecológicas, Facultad de Ciencias, Universidad de Chile, Instituto de Ecología y Biodiversidad, \\ Casilla 653, Santiago, Chile. \\ *rbustama@uchile.cl
}

\begin{abstract}
In this study, we compared demographic responses of Eschscholzia californica populations located at different altitude, under the basic assumption that altitudinal gradients impose environmental limitation to the spread at the upper edge of the gradient. We detected significant differences among populations either in terms of life history attributes and the finite rate of increase. In general, coastal population expressed higher finite population rates than mountain populations, although these differences were not statistically significant. Mountain populations (Corral Quemado and Farellones) expressed a finite population rate not significant different of 1 . These result suggest that at the upper front of invasion the species is in a demographic equilibrium because in spite of we detected a higher plant fecundity, there exist ecological constraints a seed stage level. We proposed to address more specific studies assessing from one hand, seed movement from lower altitudes and the efficiency of domestic cattle as biotic vector; we also propose to examine the feasibility of this species to establish positive interactions with cushion plants, and therefore to expand its geographic range due to this facilitation effect.
\end{abstract}

KEYwORDS: Populations, invasions, heterogeneity, demographic matrix.

\section{RESUMEN}

En este estudio comparamos las respuestas demográficas de las poblaciones de Eschscholzia californica ubicadas a diferentes altitudes, bajo el supuesto básico de que los gradientes altitudinales imponen limitaciones a la invasión. Se detectaron diferencias significativas entre las poblaciones, ya sea en términos de atributos de la historia de vida y tasa finita de crecimiento. En general, las poblaciones costeras expresaron mayores tasas de crecimiento que las poblaciones de montaña, aun cuando éstas no fueron estadísticamente significativas. Las poblaciones de montaña (Corral Quemado y Farellones) fueron las únicas que mostraron una tasa de crecimiento similar a 1. Estos resultados sugieren que las poblaciones ubicadas en el frente superior de invasión estarían en un equilibrio demográfico debido a que aun cuando se detectó una elevada fecundidad, existen restricciones ecológicas a nivel de las semillas. Proponemos hacer estudios más específicos para evaluar un posible movimiento de semillas desde altitudes más bajas y la eficiencia del ganado doméstico como vector transportador de estas semillas; proponemos también examinar la posibilidad que tiene esta planta de establecer interacciones positivas con las plantas en cojín, ubicadas a mayores alturas y, por lo tanto, ampliar su rango altitudinal debido a este efecto de facilitación.

Palabras clave: Poblaciones, invasiones, heterogeneidad, matrices demográficas.

\section{INTRODUCTION}

Biological invasions are regarded one of the major drivers of global change and represent a growing threat to biodiversity (Sala et al. 2000). Among the various phases that characterize the process of invasion, the geographic spread has intrigued for long to ecologists (Elton 1958, GarcíaRamos \& Rodríguez 2002, Hasting et al. 2005). In fact, many species are successful invader covering in some cases entire continents, thus occupying a diversity of ecosystems (Elton 1958). To understand the determinants of this spread, its magnitude as well as the ecological and evolutionary 
consequences is an urgent task to anticipate, control and prevent this global threat (Shigesada \& Kawasaki 1997, Hasting et al. 2005).

During spread, the new colonizers move across a mosaic of environmental patches which differ in habitat quality (With 2002). The persistence of individuals within these habitats will basically depend on the balance between the per capita birth rate and the per capita death rates within those patches. If this balance is positive, then the habitat patches are suitable and can sustain population growing (source populations) and eventually may constitute new foci of spread across landscapes; if the balance is negative, then the habitat is unsuitable and is unable to sustain populations (sink populations) and they will persist only with a constant flow in migration of individuals from source populations (Pulliam 1988). In this case, the invasive front is stopped and invasion is maintained in a lag-phase because the unsuitable conditions occurring there (Von Holle et al. 2003, Snyder 2003, Daehler 2009). Therefore, the assessment of the demographic processes that occur within populations is critical to determine the potentiality of invasive spread (Sakai et al. 2001, Hooftman et al. 2006, Thomson 2007).

Altitudinal gradients constitute appropriate scenarios to examine the environmental resistance to invasive species (Körner 2007). The temperature, the length of vegetational period and nutrient availability decrease with altitude, while annual precipitation, the frequency of frost during the growth period, and the solar radiation increases with altitude (Körner 2003). Clearly, the upper boundaries constitute harsh environments and represent ecological barriers to plant invasion (Alpert et al. 2000). However, there is evidence that many non-native plant species have colonized mountain environments across wide climatic and latitudinal ranges (Pauchard et al. 2009). To identify which and where are these barriers, the demographic processes that are constrained during invasion as well as the factors that enable them to surmount such barriers are critical to understand the expansion, the maintenance or even the retreat of the front of invasion in such environments (Keitt et al. 2001).

Eschscholzia californica Cham. (Papaveraceae) is an herbaceous plant original from U.S. West Coast, California. It is widely distributed from sea level to 2200 masl (Hickman 1993, Leger \& Rice 2003). It is regarded a successful invader across Mediterranean ecosystems worldwide (Leger \& Rice 2003). In Chile, it distributes from $30^{\circ}$ to $38^{\circ} \mathrm{S}$ latitude and from 0 to 2200 masl (Arroyo et al. 2000). Because of its wide geographic distribution in Chile, Eschscholzia californica is an appropriate model to examine the demographic responses of invasive plants across altitudinal gradients. If spread is constrained at upper ranges (the front of invasion), then the finite rate of increase $(\lambda)$ will be lower than 1 while it will be significantly higher than 1 at lower altitudes. The objective of this study was to compare demographic response of $E$. californica populations located at the coast and at the mountain ranges, Central Chile. In order to do that, we used matrix population models, to estimate the finite rate of increase $(\lambda)$; we also conducted a Life Table Response Experiment (LTRE) (Caswell 2001), to examine the relative contribution of vital rates to $\lambda$ differences observed between populations.

\section{MATERIALS AND METHODS}

During spring-summer 2009 and 2010, we examined the demography of five populations of $E$. californica located in two altitudinal ranges of Central Chile: (i) coast, Navidad (33 $\left.57^{\prime} \mathrm{S} ; 71^{\circ} 51^{\prime} \mathrm{W}\right)$ and Puchuncaví (32 ${ }^{\circ} 43^{\prime} \mathrm{S}$; $71^{\circ} 26^{\prime}$ $\mathrm{W})$, and (ii) mountain, Coya $\left(34^{\circ} 11^{\prime} \mathrm{S} ; 70^{\circ} 33^{\prime} \mathrm{W}\right)$, Corral Quemado (33 20' S; 70 21' W) and Farellones (33 $21^{\circ}$ $\mathrm{S} ; 70^{\circ} 19^{\prime} \mathrm{W}$ ). Climate is Mediterranean-type (Di Castri \& Hajek 1976), with a high inter-annual rainfall variability (Aceituno 1990). The sampled populations conform closed patches (aprox. $0.5 \mathrm{ha}$ ), surrounded by disturbed native vegetation, agro-ecosystems or close to roads of frequent use by people or animals. For additional information of the populations of study, see Figure 1.

We assessed the demography for each of the five populations; we disposed linear transects (at random) within populations; each 10-15 $\mathrm{m}$ apart we disposed a $1 \mathrm{~m}^{2}$ (plot); inside each plot, we counted the number of adult plants $(N)$; at the center of the plot, we extracted a volume of $100 \mathrm{~cm}^{3}$ $(10 \mathrm{~cm} \times 10 \mathrm{~cm} \times 1 \mathrm{~cm})$ soil sample; at the lab, we counted the total number of seeds and estimated seed density $(S)$, projecting these number to $1 \mathrm{~m}^{2}$. Due to different population size, the total number of sampling plots was variable among populations (Fig. 1). Inside each plot, we selected at random four-five individuals and we counted the total numbers of flowers and fruits per individual; then we collected four-five mature fruits per individual; at the lab, we counted the number of seeds per mature fruit. Thus, the adult fecundity $\left(F_{A}\right)$ was estimated multiplying the number of seeds per mature fruit by the total number of flowers and fruits produced by each individual (Table I). In this way, we obtained and average value of $F_{A}$ for each plot. In the case of Farellones and Corral Quemado, we used this information from other study; specifically, we the fecundity was obtained from adult plants located outside the sampling plots (Arredondo-Núñez 2011). Then, we randomly assigned these values to the 25 and 30 sampling plots of Corral Quemado and Farellones, respectively. We also estimated the seed rain (SR), i.e. the potential number of seeds that fall inside a sampling plot, during the reproductive period, multiplying the mean $F_{A}$ by the adult density recorded by each sampling plot.

$$
\mathrm{SR}=\mathrm{N} * \mathrm{~F}_{\mathrm{A}}
$$




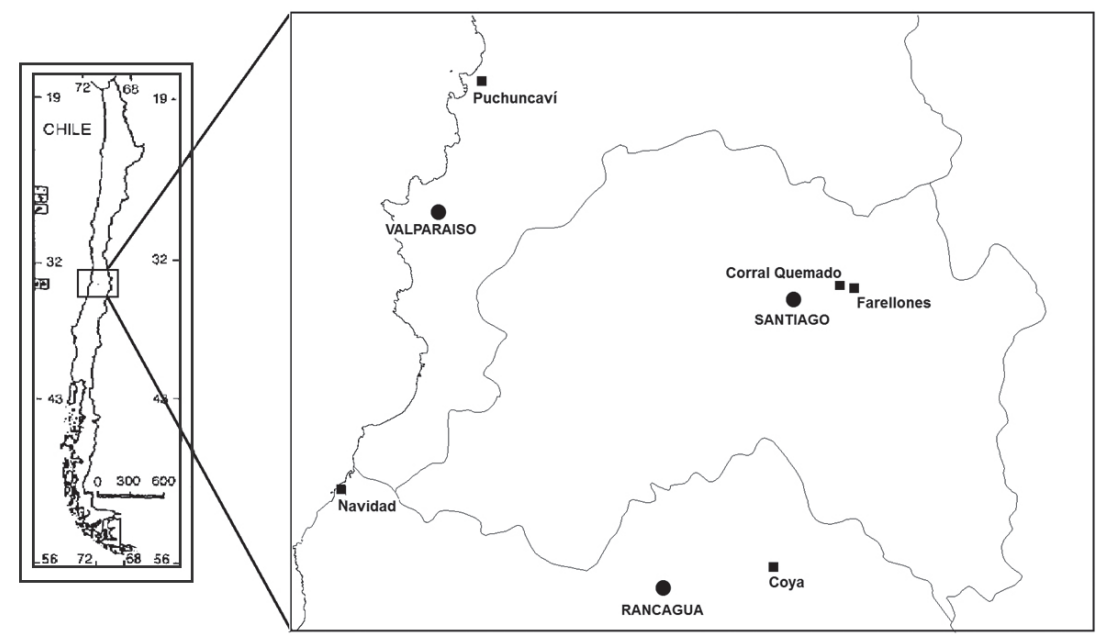

\begin{tabular}{|c|c|c|c|c|c|}
\hline Population & $\mathrm{N}^{\circ}$ & $\begin{array}{l}\text { Altitude } \\
\text { (masl) }\end{array}$ & $\begin{array}{c}\text { Annual Mean } \\
\text { Temperature }\left({ }^{\circ} \mathrm{C}\right)\end{array}$ & $\begin{array}{c}\text { AnNual Mean } \\
\text { Precipitation }(\mathrm{mm})\end{array}$ & Context \\
\hline Puchuncaví & 30 & 43 & 14.5 & 349 & Old field \\
\hline Navidad & 25 & 99 & 16.6 & 571 & Road edge \\
\hline Coya & 25 & 1076 & 11.6 & 875 & Old field \\
\hline C. Quemado & 30 & 1200 & 10.4 & 510 & Road edge \\
\hline Farellones & 30 & 2200 & 8.5 & 495 & Old field \\
\hline
\end{tabular}

FIGURE 1. Geographic locations of the five populations of study with the climatic conditions, altitude and ecological context within each locality (source http://www.worldclim.org).

FiguRA 1. Ubicación geográfica de las cinco poblaciones en estudio, incluyendo las condiciones climáticas, la altitud y el contexto ecológico de cada localidad (fuente http://www.worldclim.org).

The life cycle of Eschscholzia californica was reduced to only two stages: seeds (S) and adult plants (A) (Caswell 2001). Then, we constructed a two-stage demographic matrix which included the vital rates: $F_{A}=$ adult fecundity; $P_{S}$ and $P_{A}$, the probability of a seed and adult to survive and remain at the same stage; $R_{s}=$ the probability of a seed to develop to adult stage (Fig. 2). This life cycle clearly is a simplification; however it is biologically meaningful for the population dynamics of this species given that (i) seeds can germinate, recruit to seedling and growth to adult stage within the lapse of one year and (ii) we have some evidences suggesting that the most critical demographic bottlenecks occur during seed and seedling stage (Peña-Gómez 2009).

$P_{S}$ and $P_{A}$ were estimated indirectly following Caswell (2001). In general,

$$
\mathrm{P}_{i}=\sigma_{i}\left(1-\gamma_{i}\right)
$$

$\sigma_{i}=$ individual nrobability to survive from the stage $\mathrm{i}$ to the stage $\mathrm{i}+1 ; \gamma_{i}=$ individual probability to grow from the stage $\mathrm{i}$ to the stage $\mathrm{i}+1$. For seeds, $\sigma_{S}$ was estimated empirically, using a field experiment. Specifically, we disposed one Petri dish inside each sampling plot (50 seeds per Petri dish). After one week, we counted the number of remaining seeds $(R S)$. During the course of the experiment, we observed that seed dispersal process was occurring, so it was possible that some seeds fell inside the Petri dishes, thus increasing the number of seeds available for seed predators. To correct for this bias, we estimated the number of seeds that potentially might fall inside a Petri dish $(P)$, scaling down the information obtained for the seed rain $(S R)$. Then, this number was added to the 50 experimental seeds; then

$$
\sigma_{S}=\frac{R S}{S O+P}
$$




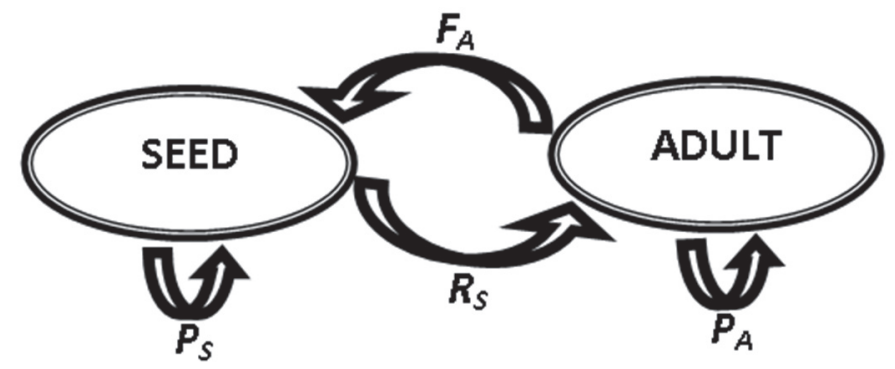

FIGURE 2. Life cycle for the invasive plant Eschscholzia californica, indicating stages of seeds (Seed) and adults (Adult) and the corresponding vital rates: $P_{S}$ and $P_{A}=$ the probability of a seed and adults to survive and remain at the same stage, $F_{A}=$ adult fecundity, $R_{S}=$ the probability of a seed to develop to adult stage.

Figura 2. Ciclo de vida de la especie invasora Eschscholzia californica indicando los estados de semillas (Seed) y adultos (Adult) y sus correspondientes tasas vitales: $P_{S}$ and $P_{A}=$ probabilidad de una semilla o un adulto de sobrevivir y permanecer en el mismo estado, $F_{A}=$ fecundidad de adultos, $\mathrm{R}_{\mathrm{S}}=$ probabilidad de una semilla de desarrollarse hasta el estado adulto.

For adults, $\sigma_{A}$ was assumed constant for both populations $\left(\sigma_{A}=0.24\right.$; Arredondo-Núñez 2011). $\gamma_{i}$ was estimated analytically using the procedure proposed by Caswell (2001)

$$
\gamma_{i}=\frac{1}{\mathrm{~T}_{i}}
$$

where $T_{i}$ is the duration time of stage i. For seeds, $T_{S}$ was estimated through germination experiments, being 365 days the lapse of time where we found seed germinating within populations; for adults, $T_{A}$ was estimated from literature (aprox. 4 years, Klotz et al. 2002). These values were considered constant for the totality of populations.

The estimation of $R_{S}$ is critical for the population dynamics as it captures most of the transition probabilities along plant life cycle. Hopefully, it should be appropriate to estimate it analytically, using the algorithms proposed by Caswell (2001); however the information required for this estimation resulted impossible in a time lapse of 1 year where we captured just a static picture of the population dynamics (one reproductive season). From previous studies (Peña-Gómez 2009), we know that recruitment process in E. californica depends on the seed bank (seed that remained in the soil more than one year), as well as by the seed rain (i.e. the seeds produced per area during one reproductive season); that is, seed originated from these two sources have the potentiality to germinate in a same time period. Then, $R_{S}$ was estimated using the expression:

$$
R s=\frac{A}{S R+S}
$$

where $A=$ adult density, $S=$ seed bank and $S R=$ seed rain.

For each population, we constructed a set of matrix models, one for each sampling plot. Then, we conducted for each matrix, a prospective analysis to obtain the finite rate of increase $\lambda$, solving the characteristic matrix equation (Caswell 2001). Additionally, we conducted a retrospective analysis, using Life Table Response Experiments (LTRE) (Caswell 2001), examining the proportional contribution of vital rates to $\lambda$ differences observed between populations. For this analysis it is not necessary to detect $\lambda$ differences between populations (Caswell 2001); it is also useful to analyze the existence of demographic trade-offs that might explain the absences of $\lambda$ differences; for instance, a positive contribution of one parameter may be compensated by negative contributions of others. The general algorithm for LTRE analysis is:

$$
\lambda^{(m)} \approx \lambda^{(r)}+\left.\sum_{i, j}\left(a_{i j}{ }^{(m)}-a_{i j}{ }^{(r)}\right) \frac{\partial \lambda}{\partial a_{i j}}\right|_{\mathrm{A}^{+}}
$$

where $\lambda^{(m)} \mathrm{y} \lambda^{(r)}$ are the finite population rate of populations $m$ and $r$ respectively. The contribution $c_{i j}$ of each vital rate $a_{i j}$ corresponds to the product between the differences observed for vital rate between populations multiplied by the average sensitivity of $\lambda$ to changes of the vital rate:

$$
c_{i j}=\left.\left(a_{i j}{ }^{(m)}-a_{i j}{ }^{(r)}\right) \frac{\partial \lambda}{\partial a_{i j}}\right|_{\mathrm{A}^{+}}
$$

$\mathrm{A}^{+}$corresponds to the average matrix obtained from matrix $\mathrm{A}^{(m)}$ and $\mathrm{A}^{(r)}$ :

$$
\mathrm{A}^{+}=\left(\mathrm{A}^{(m)}+\mathrm{A}^{(r)}\right) / 2
$$

LTRE requires to compare matrix models by pairs. This analysis was conducted at two levels: (i) regional (coastal versus mountain) and (ii) local (1200 versus 2200 masl) and 
Puchuncavi vs Navidad. At regional scale, we paired the 55 demographic matrix obtained from coastal populations (Table II) with a randomly selected sample of 55 matrix of the total of 85 matrix obtained from mountain populations (Table II). At local scale, (i) we paired the 30 demographic matrix constructed at 2200 masl with 30 randomly selected matrix of the total of 55 matrix obtained for populations located at 1200 masl and (ii) we paired the 25 matrix obtained for Navidad with a randomly selected sample of 25 matrix of a total of 30 matrix obtained for Puchuncaví (Table II). We estimated the mean contribution of each vital rate $\left(c_{i j}\right)$ to $\lambda$ changes including the $95 \%$ confidence interval.
If the $95 \%$ confidences interval crosses the zero line, then this vital rate has no significant contribution to $\lambda$ differences observed between populations.

We compared seed density, adult density, adult fecundity, seed survival and the finite rate of increase among populations. We conducted a nested ANOVA (populations nested in region) for each response variable. Given that plots within populations may be not independent each other (spatial pseudoreplicates), for the comparison between regions (coastal vs. mountain), we considered populations as true replicates; thus reducing the degree of freedom of the error term from 135 to 3 .

TABLE I. Population parameters assessed for coastal populations (Navidad and Puchuncaví) and for mountain populations (Coya, Corral Quemado and Farellones), Spring 2009 and 2010. $\mathrm{N}=$ number of sampling units $\left(1 \mathrm{~m}^{2}\right)$; values depicted in Table are averages $\pm 1.96 \mathrm{~s} . e$.

TABLA I. Parámetros poblacionales evaluados para poblaciones costeras (Navidad y Puchuncaví) y para poblaciones de montaña (Coya, Corral Quemado y Farellones), primavera 2009 y 2010. $\mathrm{N}=$ número de unidades muestrales $\left(1 \mathrm{~m}^{2}\right)$; valores en Tabla son promedios \pm 1.96 e.e.

\begin{tabular}{|c|c|c|c|c|c|}
\hline Populations & $\mathrm{N}$ & FECUNDITY & $\begin{array}{c}\text { SeEd SuRVIVAL } \\
\text { Probability }\end{array}$ & $\begin{array}{l}\text { SEED BANK }(\mathrm{SB}) \\
\quad\left(\mathrm{seed} * \mathrm{~m}^{-2}\right)\end{array}$ & $\begin{array}{c}\text { ADULT DENSITY } \\
\left(\mathrm{NA}=\text { ind } * \mathrm{~m}^{-2}\right)\end{array}$ \\
\hline \multicolumn{6}{|l|}{ COAST } \\
\hline Navidad & 25 & $1247 \pm 320$ & $0.60 \pm 0.06$ & $9371 \pm 2714$ & $4.52 \pm 0.82$ \\
\hline Puchuncaví & 30 & $3829 \pm 804$ & $0.58 \pm 0.08$ & $5379 \pm 1419$ & $2.67 \pm 0.48$ \\
\hline AVERAGE COAST & 55 & $2655 \pm 572$ & $0.59 \pm 0.04$ & $7193 \pm 1536$ & $3.51 \pm 0.52$ \\
\hline \multicolumn{6}{|l|}{ MOUNTAIN } \\
\hline Coya & 25 & $18896 \pm 8656$ & $0.15 \pm 0.06$ & $3466 \pm 2369$ & $5.24 \pm 1.05$ \\
\hline Corral Quemado & 30 & $1286 \pm 496$ & $0.31 \pm 0.10$ & $3070 \pm 401$ & $5.53 \pm 0.70$ \\
\hline Farellones & 30 & $2144 \pm 624$ & $0.47 \pm 0.04$ & $26973 \pm 8696$ & $9.47 \pm 1.57$ \\
\hline Average MOUNTAIN & 85 & $6768 \pm 3030$ & $0.32 \pm 0.04$ & $11623 \pm 3948$ & $6.84 \pm 0.79$ \\
\hline GRAND AVERAGE & 140 & $5153 \pm 1879$ & $0.42 \pm 0.04$ & $9883 \pm 2491$ & $5.53 \pm 0.59$ \\
\hline
\end{tabular}

\section{RESULTS}

Soil seed abundance did not differ significantly between mountain and coastal populations of E. californica (nested ANOVA, $\mathrm{F}_{1,3}=6.53 ; \mathrm{P}=0.08$; Table I); however, we detected significant differences among populations (nested ANOVA, $\mathrm{F}_{3,135}=46.63$; $\mathrm{P}<0.001$ ). In Navidad, the seed abundance was significantly higher than at Puchuncaví (Tukey $\mathrm{P}<0.002$ ) (Table 1); in Farellones, seed abundance was significantly higher than at Coya (Tukey $\mathrm{P}<0.001$ ) and at Corral Quemado (Tukey, P $<0.001$; Table I), while this value did not differ between Coya and Corral Quemado (Tukey $\mathrm{P}=0.8$; Table I).
Adult density was significantly higher at mountain than at coastal populations (nested ANOVA, $\mathrm{F}_{1,3}=$ 45.1; $\mathrm{P}=0.006$; Table I); we also detected significant differences among populations (nested ANOVA, $\mathrm{F}_{3,135}=$ 9.43; $\mathrm{P}<0.001$; Table I); in the case of Farellones, adult density almost doubled the values observed at Corral Quemado and at Coya (Tukey, $\mathrm{P}<0.05$; Table I); at costal populations no differences were detected at all (Tukey, $\mathrm{P}$ $>0.05$; Table I).

Fecundity did not differ between mountain and coastal populations (nested ANOVA, $\mathrm{F}_{1,3}=1.65 ; \mathrm{P}=0.29$; Table I). We detected significant differences among populations (nested ANOVA, $\mathrm{F}_{3,135}=49.74 ; \mathrm{P}<0.001$; Table I); for 
instance at mountain populations, Coya expressed the highest values of fecundity (Table I).

Seed survival was significantly higher at coastal populations than at mountain populations (nested ANOVA, $\mathrm{F}_{1,3}=68.7 ; \mathrm{P}=0.004$; Table I); we detected significant differences among populations (nested ANOVA, $\mathrm{F}_{3,135}=9.68 ; \mathrm{P}=0.002$; Table I). For instance, at mountain populations, seed survival in Farellones was not significantly different than at Corral Quemado (Tukey, $\mathrm{P}=$ 0.09 ) while it was significantly higher than at Coya (Tukey $\mathrm{P}=0.017$; Table I); on the other hand, seed survival at Corral Quemado was significantly higher than at Coya (Tukey, $\mathrm{P}=0.035$; Table I).

From the matrix analysis (demographic parameters despicted in Table II), we obtained that $\lambda$ did not differ significantly between coastal and mountain populations (nested ANOVA, $\mathrm{F}_{1,3}=6.85 ; \mathrm{P}=0.07 ;$ Fig. 3 ). However, $\lambda$ differed significantly among populations (nested ANOVA, $\mathrm{F}_{3,135}=11.04 ; \mathrm{P}<0.001 ;$ Fig. 3); for instance, at coastal populations, $\lambda$ was significantly higher at Puchuncaví than at Navidad (Tukey $\mathrm{P}<0.001$; Fig. 3); at the mountain populations, Coya was the only population whose $\lambda$ was significantly different than one (Fig. 3), and at Corral Quemado and Farellones, it was not significantly different each other (Tukey $\mathrm{P}=0.96$; Fig. 3 ) ; in both cases, this value was not significantly different than one (Fig. 3).

The LTRE analysis showed that at regional scale, $P_{S}$ contributed positively and significantly to $\lambda$ differences between coastal and mountain populations, while $F_{A}$ and $R_{S}$ did not contribute significantly to $\lambda$ differences at all (Fig. 4A). At a local scale, $P_{S}$ contributed negatively and significantly to $\lambda$ differences between 1200 and 2200 (Fig. 4B), while neither F nor $R_{S}$ contributed significantly to $\lambda$ differences. A different picture emerged when we compared coastal populations (Puchuncavi and Navidad): $P_{S}$ did not contribute to $\lambda$ differences while $F_{A}$ contributed positively and $R_{A}$ contributed negatively to $\lambda$ differences (Fig. 4C).

TABLE II. Vital rates assessed for coastal (Navidad and Puchuncaví) and mountain populations of E. californica (Coya, Corral Quemado and Farellones), for demographic analysis using matrix models, Spring 2009 and 2010. $F_{A}=$ fecundity; $P_{S}=$ probability of seed survival and permanency; $R_{S}=$ seed recruitment probability; $\lambda$ = finite rate of increase. $\mathrm{N}=$ number of demographic matrix estimated for each population. For the totality of populations, $P_{A}=0.2398$ (for more details see text). Values depicted in Table are averages \pm 1.96 s.e.

TABLA II. Tasas vitales evaluadas para poblaciones costeras (Navidad y Puchuncaví) y para poblaciones de montaña de $E$. californica (Coya, Corral Quemado y Farellones) para realizar análisis demográfico usando modelos matriciales, primavera 2009 y $2010 . F_{A}=$ fecundidad; $P_{S}$ $=$ probabilidad de que una semilla sobreviva y permanezca como semilla; $R_{S}=$ probabilidad de una semilla de reclutar al estado adulto; $\lambda=$ tasa finita de crecimiento. $\mathrm{N}=$ número de matrices demográficas estimadas para cada población. Para la totalidad de las poblaciones $P_{A}=$ 0.2398 (para más detalles véase texto). Los valores que se muestran en Tabla son promedios \pm 1.96 e.e.

\begin{tabular}{|c|c|c|c|c|c|}
\hline Populations & $\mathrm{N}$ & $\mathrm{F}_{\mathrm{A}}$ & $\mathrm{P}_{\mathrm{S}}$ & $\mathrm{R}_{\mathrm{s}}$ & $\lambda$ \\
\hline \multicolumn{6}{|l|}{ COAST } \\
\hline Navidad & 25 & $\begin{array}{c}1247.36 \pm \\
320.08\end{array}$ & $0.55 \pm 0.06$ & $\begin{array}{c}0.00039 \pm \\
0.00011\end{array}$ & $1.05 \pm 0.05$ \\
\hline Puchuncaví & 30 & $\begin{array}{c}3828.78 \pm \\
803.75\end{array}$ & $0.53 \pm 0.07$ & $\begin{array}{c}0.00022 \pm \\
0.00005\end{array}$ & $1.21 \pm 0.04$ \\
\hline AvERAGE COAST & 55 & $\begin{array}{c}2655.41 \pm \\
572.25\end{array}$ & $0.54 \pm 0.04$ & $\begin{array}{c}0.00030 \pm \\
0.00006\end{array}$ & $1.14 \pm 0.04$ \\
\hline \multicolumn{6}{|l|}{ MOUNTAIN } \\
\hline Coya & 25 & $\begin{array}{c}18896.60 \pm \\
8656.03\end{array}$ & $0.14 \pm 0.05$ & $\begin{array}{c}0.00014 \pm \\
0.00005\end{array}$ & $1.16 \pm 0.02$ \\
\hline Corral Quemado & 30 & $\begin{array}{c}1285.50 \pm \\
496.03\end{array}$ & $0.29 \pm 0.09$ & $\begin{array}{c}0.00072 \pm \\
0.00013\end{array}$ & $1.03 \pm 0.08$ \\
\hline Farellones & 30 & $\begin{array}{c}2144.33 \pm \\
623.80\end{array}$ & $0.43 \pm 0.04$ & $\begin{array}{c}0.00027 \pm \\
0.00005\end{array}$ & $1.00 \pm 0.06$ \\
\hline AVERAGE MOUNTAIN & 85 & $\begin{array}{c}6165.91 \pm \\
3063.46\end{array}$ & $0.29 \pm 0.04$ & $\begin{array}{c}0.00039 \pm \\
0.00007\end{array}$ & $1.06 \pm 0.06$ \\
\hline TOTAL AVERAGE & 140 & $\begin{array}{c}4786.78 \pm \\
1890.65 \\
\end{array}$ & $0.39 \pm 0.04$ & $\begin{array}{c}0.00035 \pm \\
0.00005\end{array}$ & $1.09 \pm 0.03$ \\
\hline
\end{tabular}




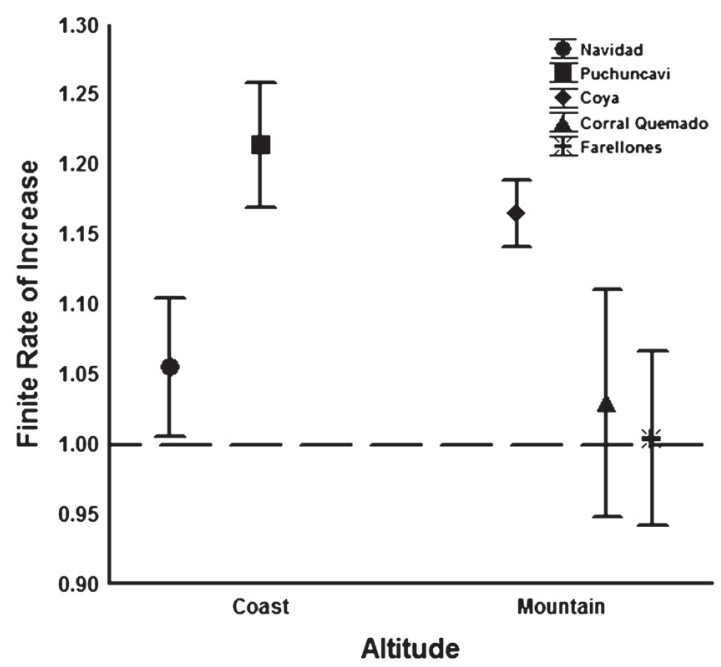

FIGURE 3. Finite rate of growth $(\lambda)$ estimated for different populations of Eschscholzia californica located at the coast and mountains, Spring 2009 and 2010, Central Chile. Values represent averages \pm 1.96 standard error. Dotted line represent $\lambda=1$.

Figura 3. Tasa finita de crecimiento $(\lambda)$ estimada para diferentes poblaciones de Eschscholzia californica en poblaciones costeras y de montaña, primavera 2009 y 2010, Chile central. Los valores indicados representan promedios $\pm 1,96$ errores estándar. Línea discontinua representa $\lambda=1$.

\section{DISCUSSION}

In this study, we compared demographic responses of a set of Eschscholzia californica populations located at lower and at higher altitudes, under the basic assumption that altitudinal gradients impose environmental limitation to exotic plant regeneration at the upper edge of the gradient. At the coast, adult density was significantly lower than at the mountains while seed survival was significantly higher at coastal populations; additionally, seed density and fecundity did not varied between coast and mountain (Table I). Moreover, we detected significant variation among populations in the totality of parameters assessed in the field, thus suggesting subtle significant environmental variation even at similar altitudes.

How do these numbers expressed in the finite rate of increase? This value did not vary between coastal and mountain populations. In general, populations expressed an exponential population growth $(\lambda>1)$ with the exception of Corral Quemado (1200 masl) and Farellones (2200 masl) whose $\lambda$ did not differed significantly of 1 . Additionally, we detected significant demographic variation either within coastal populations i.e. $\left(\lambda_{\text {Navidad }}<\lambda_{\text {Puchuncavi }}\right)$ as well as within mountain populations $\left(\lambda_{\text {Farellones }}=\lambda_{\text {Corral Quemado }}<\lambda_{\text {Coya }}\right)$.

Our results demonstrate that at higher the upper edge of the altitudinal gradient, the invasive process of E. californica is constrained; at higher altitude, the finite rate of growth was 1 (see the case of Farellones and Corral Quemado), i.e. the populations are at equilibrium, thus the front of invasion is stopped. How can we explain this constraint? From the LTRE we found that $P_{S}$ was particularly sensitive at higher altitude either at regional or at local scale (Figs. 4A and B). Given that this parameter integrates basically seed survival and the potential of seeds to persist in the soil (seed bank), our results highlight the importance to examine the processes that determine the seed fate (viability, germination, survival) across altitudinal gradients (Arroyo et al. 1999, Körner 2003). In our case, we demonstrated that seed survival was more limited at higher altitudes by an increase of seed predation (Muñoz \& Arroyo 2002, Muñoz \& Cavieres 2006) and presumably by a limitation to seed germination and seedling establishment due to water stress existing at higher altitudes during the plant growth period; in fact we have observed seed germination in the field, but scarce seedling survive to the next season (Peña-Gómez 2009).

For native plants, it has been documented that later stages of life cycle (juveniles-adults) are sensitive at higher altitude because they are largely exposed to physical disturbances, water stress and/or the snow covering (Cavieres \& Arroyo 1999), thus decreasing plant performance and reproduction (Körner 2003, Johnston \& Pickering 2004, Becker et al. 2005, MacDougall et al. 2006). The demography of E. californica, suggests that this is not the case, and the fate of seeds within the seed bank seems to be critical for the population outcome. Additionally, $F_{A}$ could be experiencing some demographic constraint as well because it contributed positively to $\lambda$ changes between 1200 and 2200 masl (average aprox. 0.20; Fig. 4b). This limitation may be consequence of lower temperature concomitantly with the scarcity of pollinators, thus reducing plant seed set at higher altitude.

Other result that emerged from our study is the notable $\lambda$ variations between populations. For instance, at Coya (located at mountains), the population expressed a similar demography to coastal populations while at Navidad (coastal), the population expressed a similar demography to mountain populations. This variation could be related to subtle habitat variability (not assessed in this study) and clearly prevented us to find statistical differences between coastal and mountain zones in spite that at the coast $\lambda$ was in average aprox. $15 \%$ higher than at the mountains $(P$-value $=0.07)$.

LTRE, conducted between Puchuncaví and Navidad (population located at the coast), allowed to detect a different demographic pattern compared with mountain populations. $P_{s}$ did not contributed significantly to $\lambda$ changes $\left(P_{S}\right.$ was very important at mountain populations) while $F_{A}$ was the parameter that contributed more importantly to the higher $\lambda$ values obtained for Puchuncaví. On the other hand, $R_{A}$ contributed negatively and significantly to $\lambda$ differences, however it was not enough strong to compensate the positive contribution of $F_{A}$. We do not know the causes of these demographic differences between coastal and mountain populations. 

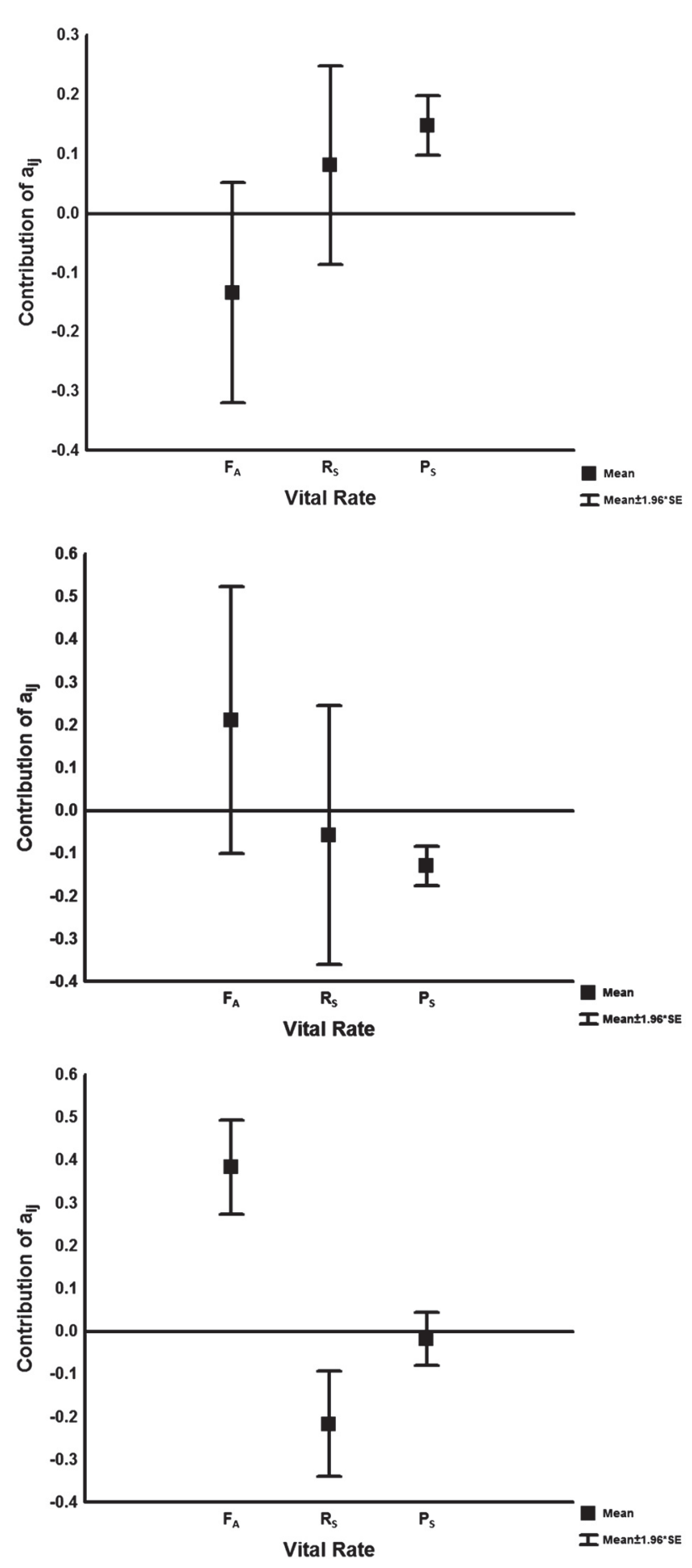

FIGURE 4. Relative contribution of vital rates to $\lambda$ differences in Eschscholzia californica between A) coast and mountains, B) 1200 and 2200 masl populations and C) Puchuncaví and Navidad, Central Chile

FIGURA 4. Contribución relativa de las tasas vitales a las diferencias en $\lambda$ en Eschscholzia californica entre A) costa y montaña, B) entre 1.200 y 2.200 m s.n.m. and C) Puchuncaví and Navidad, Chile Central.
Our results have two important implications. Firstly, the demographic equilibrium detected at the front of invasion, poses limitation to the possibility of seed movement to higher altitude. However, it is possible to expect seed movement from lower altitudes, where there is an effective a surplus of seeds. We have observed cows and horses consuming actively reproductive structures of E. californica (flowers and mature fruits); domestic cattle which can be abundant in alpine ecosystems (Körner 2003), could be good candidates to transport seeds from lower to higher altitudes, a mechanism that has been well documented for other exotic plants (Richardson et al. 2000, Gosper et al. 2005). The next step is to test the existence of seed movement, either directly, examining cattle feces or indirectly, estimating gene flow using genetic techniques. Secondly, if cows are efficient vectors, the seeds can be transported beyond the current invasion front of this exotic plants (2200 masl) to the cushion plants zone (Laretia acaulis, Azorella monantha and Azorella madreporica) which range from 2800 to 3400 masl (Armesto et al. 1980); this seed movement is plausible as we have observed horses feces above 3000 masl and beyond. It is well documented that cushion plants provide microclimate conditions for exotic plants, which increase growth, survival and reproduction on species such as Taraxacum officinale and Cerastium arvensis (Cavieres et al. 2006, Badano et al. 2007, Arredondo et al. 2009). Therefore, it is probable that this positive interaction might occur with Eschscholzia californica as well. A critical issue here is to test if seed mortality by predation will decrease with altitude. Currently, there are no direct evaluations of seed predation within the altitudinal band of cushion plants; it could be interesting to examine if these plants can act as safe sites for seeds and seedlings against predators (Harper 1977). There are some recent evidences that suggest that plant predation decreases with altitude, then seeds and seedlings could decrease predation risk at higher altitudes (Giménez-Benavides et al. 2007).

In summary, although at the front of invasion $E$. californica populations may be in a demographic steady-state, we propose that this species has the potentiality to increase the altitudinal range, via biotic interactions with domestic cattle, which have the potentiality to transport seeds to the zone of cushion plants which in turn provide shelter against abiotic stress. Further research is needed to examine these mechanisms, their generality and importance to understand invasive processes in native mountain ecosystems.

\section{ACKNOWLEDGEMENTS}

This study was funded by project FONDECYT 1100076 , and partially by the project ICM - P05 - 002 . 


\section{REFERENCES}

Aceituno, P. 1990. Anomalías climáticas en la región sudamericana durante los extremos de la oscilación austral. Revista Geofísica 32: 65-78.

Alpert, P., E. Bone \& C. Holzapfel. 2000. Invasiveness, invisibility and the role of environmental stress in the spread of nonnative plants. Perspectives Plant Ecology 3: 52-66.

Armesto, J.J., M.T.K. Arroyo \& C. Villagrán. 1980. Altitudinal distribution, cover and size structure of umbelliferous cushion plants in the high Andes of Central Chile. Acta Oecologica 1: 327-332.

Arredondo-NúÑEZ, A. 2011. Diferenciación de los sistemas reproductivos y despliegues florales en Eschcholzia californica (Papaveraceae) en un gradiente altitudinal. Tesis Magíster, Universidad de Chile. 36 pp.

Arredondo-NúÑez, A., E.I. Badano \& R.O. Bustamante. 2009. How beneficial are nurse plants? A meta-analysis of the effects of cushion plants on high-Andean plant communities. Community Ecology 10: 1-6.

Arroyo, M.T.K., L.A. Cavieres, C. Castor \& A.M. Humaña. 1999. Persistent soil seed bank and standing vegetation at a high alpine sita in the Central Chilean Andes. Oecologia. 119: 126-132.

Arroyo, M.T.K., C. Marticorena, O. Matthei \& L.A. Cavieres. 2000. Plant invasions in Chile: presents patterns and future predictions. In: H.A. Mooney \& R. Hobbs (eds.), Invasive Species in a Changing World. pp.: 385-421. Island Press, Washington, DC.

Badano, E.I., E. Villarroel, R.O. Bustamante, P.O. Marquet \& L.A. CAVIERES. 2007. Ecosystem engineering facilitates invasions by exotic plants in high-andean ecosystems. Journal of Ecology 95: 682-688.

Becker, T., H. Dietz, R. Billeter, H. Buschmann \& P.J. Edwards. 2005. Altitudinal distribution of alien plant species in the Swiss Alps. Perspectives in Plant Ecology, Evolution and Systematics 7: 173-183.

Caswell, H. 2001. Matrix Population Models: Construction, Analysis, and Interpretation. 2nd ed. Sinauer Associates, Inc., Massachusetts. 722 pp. CAvieres, L.A. \& M.T.K. Arroyo. 1999. Tasa de enfriamiento adiabático del aire en el Valle del Río Molina, Provincia de Santiago, Chile central $\left(33^{\circ} \mathrm{S}\right)$. Revista Geográfica Terra Australis 44: 7986.

Cavieres, L.A., E.I. Badano, A. Sierra-Almeida, S. GómezGonzÁlez \& M. Molina-Montenegro. 2006. Positive interactions between alpine plant species and the nurse cushion plant Laretia acaulis do not increase with elevation in the Andes of central Chile. New Phytologist 169: 5969.

DAehler, C.C. 2009. Short lag times for invasive tropical plants: evidence from experimental plantings in Hawai'i. PLoS ONE 4: 1-5.

Di CAstri, F. \& E. Hajek. 1976. Bioclimatología de Chile. Eds. Pontificia Universidad Católica de Chile, Santiago, Chile. $163 \mathrm{pp}$.

Elton, C. 1958. The ecology of invasions by animals and plants. University of Chicago Press.

García-Ramos, G. \& D. Rodríguez. 2002. Evolutionary speed of species invasion. Evolution 56: 661-668.
Giménez-Benavides, L., A. Escudero \& J. Iriondo. 2007. Local adaptation enhances seedling recruitment along an altitudinal gradient in a high mountain Mediterranean Plant. Annals of Botany 99: 723-734.

Gosper, C.R., C.D. Stansbury \& G. Vivian-Smith. 2005. Seed dispersal of fleshy-fruited invasive plants by birds: contributing factors and management options. Diversity and Distributions 11: 549-558.

Harper, J.L. 1977. Population biology of plants. Academic Press, London. $892 \mathrm{pp}$.

Hasting, A., K. Cuddington, K.F. Davies, C.J. Dugaw, S. Elmendorf, A. Freestone, S. Harrison, M. Holland, J. Lambrinos, U. MalvadKar, B.A. Melbourne, K. Moore, C. TAYLOR \& D. Thompson. 2005. The spatial spread of invasions: new developments in theory and evidence. Ecology Letters 8: 91-101.

Hickman, J.C. 1993. The Jepson Manual: Higher Plants of California. University of California Press, Berkeley, California. 1415 pp.

Hooftman, D.A.P., J.C.M. Oostermeijer \& J.C.M. DEN NiJs. 2006. Invasive behavior of Lactuca serriola (Asteraceae) in the Netherland: spatial distribution and ecological amplitude. Basic and Applied Ecology 7: 507-519.

Johnston, F.M. \& C.M. Pickering. 2004. Effect of altitude on resource allocation in the weed Achillea millefolium (yarrow, Asteraceae) in the Australian alps. Australian Journal of Botany 52: 639-646.

KeitT, T.H., M.A. Lewis \& R.D. Holt. 2001. Allee effect, invasion pinning and species' borders. The American Naturalist 157: 203-216.

Klotz, S, I. KÜHN \& W. DurKa. 2002. A database with biological and ecological characteristics of the flora of Germany. Schriftenreihe für Vegetationskunde (BIOLFLOR). 38: 1334.

KÖRNER, C. 2003. Alpine plant life. Functional plant ecology of high mountain ecosystem, 2nd edn. Springer, Berlin. $350 \mathrm{pp}$.

KöRnER, CH. 2007. The use of "altitude" in ecological research. TREE 22: 569-574.

Leger, E.A. \& K.J. Rice. 2003. Invasive California poppies (Eschscholzia californica Cham.) grow larger than native individuals under reduced competition. Ecology Letters 6: 257-264.

MacDougall, A.S., J. Boucher, R. Turkington \& G.E. Bradfield. 2006. Patterns of plant invasion along an environmental stress gradient. Journal of Vegetation Sciences 17: 11009233.

Muñoz, A.A. \& M.T.K. Arroyo. 2002. Post-dispersal seed predation on Sisyrinchiun arenarium (Iridaceae) at two elevations in the Central Chilean Andes. Artic, Antarctic and Alpine Research 34: 178-184.

Muñoz, A.A. \& L. CAVIERES. 2006. A mult-species assessment of post-dispersal seed predation in the Central Chilean Andes. Annals of Botany 98: 193-201.

Pauchard, A., C. Kueffer, H. Dietz, C. Daehler, J. Alexander, P.J. Edwards, J.R. Arévalo, L. Cavieres, A. Guisan, S. Haider, G. Jakovs, K. McDougall, C.I. Millar, B.J. NaYlor, C.G. PARKs, L.J. Rew \& T. SeIPEL. 2009. Ain't no mountain high enough: plant invasion reaching new elevations. Frontiers in Ecology and the Environment 7: 479-486.

Peña-Gómez, F.T. 2009. Dinámica del banco de semillas de 
Eschscholzia californica en un gradiente altitudinal: consecuencias para la regeneración. Tesis, Universidad de Chile, Chile. 27 pp.

Pulliam, H.R. 1988. Sources, sinks and population regulation. The American Naturalist 132: 652-661.

Richardson, D.M., N. Allsopp, C.M. D’antonio, S.J. Milton \& M. REJMANEK. 2000. Plant invasions: the role of mutualisms. Biological Review 75: 65-93.

Sakai, A.N., F. Allendorf, J.S. Holt, D.M. Lodge, J. Molofsky, K.A. With, S. Baughman, R.J. Cabin, J.E. Cohen, N.C. Ellstrand, D.E. McCauley, P. O’Neil, I.M. Parker, J.N. Thompson \& S.G. Weller. 2001. The population biology of invasive species. Annual, Review Ecology and Systematics 32: 305-332.

Shigesada, N. \& K. KaWASAKI. 1997. Biological Invasions: theory and practice. Oxford University Press. 205 pp.

Sala, O.E., F.S. Chapin, J.J. Armesto, E. Berlow, J. Bloomfield, R.
Dirzo, E. Huber-Sanwald, L.F. Huenneke, R.B. Jackson, A. Kinzig, R. Leemans, D.M. Lodge, H.A. Mooney, M. Oesterheld, N.L. Poff, M.T. Sykes, B.H. Walker, M. WALKER \& D.H. WALL. 2000. Global Biodiversity Scenarios for the Year 2100. Science 287: 1770-1774.

SNYDER, R. 2003. How demographic stochasticity can slow biological invasions. Ecology 84: 1333-1339.

Thomson, D.M. 2007. Do source-sink dynamics promote the spread of an invasive grass into a novel habitat? Ecology 88: 3126-3134.

Von Holle, B., H. Delcourt \& D. Simberloff. 2003. The importance of biological inertia in plant community resistance to invasion. Journal of Vegetation Science 14: 425-432.

With, K. 2002. The landscape ecology of invasive spread. Conservation Biology 16: 1192-1203.

Recibido: 08.08.11

Aceptado: 06.01.12 